\title{
Boundaries, Barriers and Bridges: Comparative Findings from European Neighbourhoods
}

\author{
Ferruccio Pastore and Irene Ponzo
}

\section{Five Key Ingredients of Neighbourhood-Level Boundary-Making}

In our boundary-making perspective, ethnicity (regarded as the result of actors' interactions and definitions) is just one among several possible lenses used to apprehend social situations, alongside others such as profession, class, and place of residence (Taboada Leonetti 1989; Lamont 2009; Lamont and Small 2008). Informed by this assumption, we have looked not only at migration-generated ethnic cleavages but also at other divisions emerging in the empirical fieldwork. Consistently with what has also been suggested by theorists of 'super-diversity' (Vertovec 2006), we have focused particularly on the way in which these different divisions interact with those generated by migration in structuring groups, considering how and to what extent they overlap, and whether they weaken or reinforce each other.

Before analyzing the boundaries found through our fieldwork, it is worth remembering that they by no means have the same significance and relevance everywhere. First of all, the significance of the various boundaries and their salience in structuring mobilization and conflicts varies across countries (Lamont 2009; Lamont and Small 2008). Also within countries, and indeed within the same city, it emerges clearly how boundaries have different relevance in different situations making it a matter of empirical analysis to determine how these boundaries concretely work in specific circumstances (Wimmer 2008). This is precisely what we have attempted in analyzing and comparing the role of recent, and less recent, migration flows in

Sections 1 and 2 are by Irene Ponzo, Sects. 3 and 4 are by Ferruccio Pastore.

F. Pastore $(\square) \bullet I$. Ponzo

FIERI, Torino, Italy

e-mail: ferruccio.pastore@fieri.it; ponzo@fieri.it 
shaping, shifting or blurring boundaries among groups in the eleven European neighbourhoods analyzed in previous chapters.

According to our findings, ethnicity remains one of the most relevant inter-group cleavages. However, this is experienced differently in different contexts, depending on nationally and locally specific histories. The majority and minorities can indeed have very different profiles which, even at neighbourhood level, are strongly influenced by national, regional or city-level cognitive frames and rhetoric. In more recent immigration countries (Italy, Spain), the cleavage is predominantly understood as being between a 'native' majority and one or several 'migrant' minorities. In older immigration countries (UK, Germany), ethnic minorities are less closely associated with migration: in British neighbourhoods, for instance, 'black' is altogether a well-established marker of identity and in German neighbourhoods former Soviet Union citizens who mostly have German origins and German nationality are nevertheless perceived as a minority group. In countries still in an embryonic phase of the immigration cycle, such as Hungary, immigration is not really an issue and the main cleavage is between an ethnic majority and historic national minorities (e.g. Roma) rather than migrants as such. From this point of view, the eccentricity of Budapest neighbourhoods in our gallery of case studies confirms the persisting specificity in the framing of international immigration in Eastern Europe as opposed to both established western and northern European destinations, and to more recent southern European receiving countries (Okólski 2012; Tryandafillidou and Gropas 2014).

Within these macro and well-known frames, we identified finer cleavages by looking ethnographically at inter-group relations in everyday experience and in specific places. One of the most evident results is that the visibility of a certain group influences the criteria of its identification: the more visible a group is, the more precise are the criteria of its identification. For instance, the most visible groups are often identified with countries of origin whereas smaller groups are identified with broader geographical areas. South Americans, for instance, are not distinguished by country of origin in most neighbourhoods, except for some Barcelona areas and for San Paolo in Turin, where they are numerous. Chinese, who represent a sizeable minority almost everywhere, are addressed as such. In Budapest's neighbourhoods, however, where the presence of foreigners is still low, people are less likely to distinguish groups by country of origin and they usually use 'Asians' and 'Chinese' interchangeably to refer to all migrants from the Asian continent including for instance Vietnamese. Visibility, however, does not depend only on the group's size but also on its presence in public places. For instance, in Sagrada Família the number of registered Pakistani residents is very low ( $0.2 \%$ of total population) but they are well recognized due to the presence of several Pakistani grocery stores. Also Romanians, who account for only $0.4 \%$ of neighbourhood residents, are identified as such by residents due to their visibility, often associated with negative stigmas (begging, pick-pocketing tourists).

While the cleavage between ethnic majority and minorities remains central, age, length of stay and socio-economic conditions have also emerged as being specifically relevant in most of our target neighbourhoods. Intergenerational cleavages, in 
particular, have been registered across several case studies: elderly people frequently portray both majority and minority young generations as less willing to take care of public places or actively engage in the neighbourhood's civic life. For instance, in many Sagrada Família associations, like the Residents' Association, the majority of day-to-day active participants are elderly or mature people who blame young people for not actively participating in local civic life. In Barriera di Milano, several elderly residents lament the communication difficulties with the new generations, for, among other reasons, the decline in the transfer of handicraft know-how and skills that were once important neighbourhood assets. In Bermondsey the majority of the White British population is made up of elderly residents who often perceive themselves in opposition to a younger population of immigrants and ethnic minorities, often with children, who have arrived in recent years and do not share their memory and ideal of estates as social places. Similarly, in the German neighbourhood of Werderau long-established elderly residents accuse the youth, mainly of Turkish origin, of not sticking to the 'old order', for instance by not keeping the neighbourhood clean, making noise and adopting other 'uncivil' behaviours. In both cases, elderly people paradoxically stand out as among the least integrated groups since they do not feel at home in their own changing neighbourhood and are strongly and nostalgically linked to a mythical past now disappeared.

Their feeling of distance from younger residents is largely independent from ethnicity, but where they overlap, ethnic and generational cleavages can indeed be mutually reinforcing. As for ethnic boundaries among youngsters, they are usually more blurred, with some notable exceptions. Inter-group tensions can be intensified by mediatization of origin-based groupings, as in the cases of 'Latin American gangs' in Sagrada Família and Poble Sec or 'black gangs' in Camberwell. Yet, local belonging and specific notions of territoriality seem to be very important in shaping and structuring these youth groups, often more than ethnic origin or belonging. ${ }^{1}$

Socio-economic conditions are certainly another crucial factor in structuring cleavages, but they may operate in very different and sometimes counter-intuitive ways. For instance, in Barcelona's Sagrada Família, economic difficulties shared by natives and immigrants living in the area called Encants Vells seem to foster reciprocal understanding so that immigrants there generally do not seem to be stigmatized. This goes against easy and widespread prophecies that the economic crisis, which was getting more acute during our fieldwork, would necessarily fuel interethnic tensions starting from the most severely hit local contexts, such as some of our southern European target neighbourhoods. In the final part of this chapter we will come back to some possible explanations for this crucial and puzzling question, which is, however, certainly deserving of continued monitoring and additional research.

In Bermondsey, in the former docklands area occupied by the Jacob's Island development, a key issue is the juxtaposition of the affluent gated communities and

\footnotetext{
${ }^{1}$ It is worth noting that Body-Gendrot (2002) has found the same attachment to local territories among young people in French banlieues: religious and ethnic differences are perceived as secondary to belonging to the collective space of the neighbourhood.
} 
the relatively deprived housing estates nearby. This divide is generated by economic disparities but also by the deeply rooted stigma concerning council housing. So while they live in immediate proximity, there is altogether very limited common ground - in terms of shared spaces and interests - between these two communities in this part of Bermondsey. Finally, in our comparative fieldwork, we also identified cases of immigrants living in a gated community. In Kőbánya the wealthiest group is made up of Asians rather than Hungarians. Thus, it is primarily more affluent people of Asian origin who live in a residential compound like Taraliget, which is enclosed by a high fence.

Religion is another relevant criterion of identification and grouping, although it appears less crucial at the local level than it has become, especially with regard to Islam, in national-level political and public discourses in Europe during the last two decades. In Werderau, despite the relevant presence of Turkish immigrants, religion was not regarded as a cleavage in the past and it only became a marker of identity when conflicts arose between old residents and new Turkish residents. The tensions seem to be mainly related to control over the housing stock but have been framed as ethnic and even religious cleavages. Due to these housing tensions that crosscut the Turkish minority itself, intra-community religious tensions also emerged between, on the one hand, old-established residents with a Turkish background who interpret Islam in a more open manner, and newly-arrived residents who follow stricter and more traditional rules of religious behaviour (headscarf, regular mosque attendance etc.), on the other hand. The role of religion as a marker of identity was also emphasized by residents in both of the London neighbourhoods that were studied. While some of the White British volunteers and community activists working locally in Bermondsey referred to their Christian belief as a major motivating factor, in Camberwell affiliation to West African churches was seen as an important and structuring aspect of everyday life and social organization, particularly by Black African respondents.

In southern European neighbourhoods, religion and nationality often overlap, and are usually evoked in a conflated and confused manner. In Barriera di Milano, natives often create confusion when they assign people to various categories: religious identity (being a Muslim) is used interchangeably with national belonging (being a Moroccan) and language (being Arabic-speaking). In Sagrada Família, the term 'Muslims' constitutes a group label applied by interviewees in an encompassing way to cover both Pakistanis and Moroccans.

Finally, the length of stay can separate or unite residents across geographical and/or ethnic lines. In Werderau established residents, of both native and Turkish background, tend to disagree with the lifestyle of new inhabitants of Turkish origin. In Italian neighbourhoods, differences emerge within larger and long-established minorities. In San Paolo, native residents frequently state that the earlier Moroccan immigrants were more inclined to incivilities and even crime whereas Moroccan newcomers are considered to be individuals who strive to legalize their situation and be fully included in the host community. In contrast, in Barriera di Milano, the Moroccans who arrived at the end of the 1970s are depicted by natives as honest and hardworking, while recently arrived Moroccans are portrayed as menacing, immoral 
and unscrupulous. This difference between the two Italian neighbourhoods is probably due to the fact that San Paolo has become a sort of second-step destination for settled families whereas Barriera di Milano has increasingly become a first destination for newcomers regarded as less integrated than long-established migrants who are rather assimilated and have started families there.

Usually, even immigrants classify themselves according to the period of their arrival in the neighbourhood. In Barriera di Milano the early-comers depict themselves as being more open to interactions and less problematic, differentiating themselves from latecomers to whom they attribute behaviours more disturbing for the established social order. A meaningful example is found in the Senegalese community: those who migrated in the first wave emphasize their work ethic and their rigid compliance with the religious norms of the Mourid Brotherhood (Carter 1997), to which they all belong, and they complain that such good habits have been abandoned by their young fellow countrymen, some of whom are involved in drug-pushing.

Similarly, in British neighbourhoods, the term 'black' refers to a number of ethnic and national categories - Black Caribbeans, West Africans, Somalis characterized by significant divides as well as occasional tensions. These distinctions based on origin usually overlap with those based on length of stay. The Black African population in Camberwell has been growing rapidly since the 1980s. By 2001 it was approximately twice the size of the Black Caribbean population which, dating back to the Windrush generation of the 1950s, historically constituted the dominant minority in the neighbourhood. Whereas some of the West Indians have adopted religious and/or cultural practices connecting them to an ideal African heritage - such as converting to Rastafarianism, collecting and displaying African artefacts, or wearing West African garments - there is also a history of tensions between them and West Africans, with some of the latter claiming that 'they say we sold them'. Another component, and the most significant one among recent black immigrants, is that of the Somalis, most of whom arrived in the late 1990s and 2000s. Somali respondents have described feeling othered, and at times stigmatized, by other black residents on account of their religion and immigrant status. We can then see that, especially in old migration countries such as Britain, the very concept of 'majority' is a slippery and unstable construction which cannot be equated to whiteness, and also that within minorities we constantly find ongoing negotiations of racial and cultural sameness and difference (Ray et al. 2008). Therefore, we can say that groups are never homogeneous and are rarely perceived as such, especially by their own members.

These boundaries have different significance not only between neighbourhoods, but also within the same neighbourhood, between 'sites of interactions' in concrete urban places and everyday experience. Here we just give some examples drawn from the previous chapters and final city reports of the Concordia Discors project (www.concordiadiscors.eu), with reference to specific interaction sites among those researched in-depth. In order to go beyond an anecdotal description of concrete cases, we have sketched a typology of relations based on the distinction, explained in the Introduction, between representations (what people have in mind) and 
Table 1 Patterns of inter-group relations and representations

\begin{tabular}{|c|c|c|c|}
\hline \multirow[b]{2}{*}{ Relations } & \multicolumn{3}{|l|}{ Representations } \\
\hline & Positive & Indifference & Negative \\
\hline Cooperation & $\begin{array}{l}\text { Different ethnic } \\
\text { groups in the } \\
\text { secret garden on } \\
\text { D'Eynsford Estate } \\
\text { in Camberwell } \\
\text { (UK) }\end{array}$ & $\begin{array}{l}\text { Chinese families } \\
\text { and elderly } \\
\text { Hungarian nannies } \\
\text { in Taraliget } \\
\text { Residential Park in } \\
\text { Kőbánya (HU) }\end{array}$ & $\begin{array}{l}\text { Chinese traders and } \\
\text { Roma employees in } \\
\text { Four Tigers Market in } \\
\text { Józsefváros (HU) }\end{array}$ \\
\hline Lack of contact & $\begin{array}{l}\text { Elderly people, } \\
\text { teenagers and } \\
\text { mothers with } \\
\text { children in SPA } \\
\text { garden in San } \\
\text { Paolo (ITA) }\end{array}$ & $\begin{array}{l}\text { Pakistanis and } \\
\text { natives in Poble } \\
\text { Sec (SPA) }\end{array}$ & $\begin{array}{l}\text { Affluent middle-class } \\
\text { residents in redeveloped } \\
\text { docklands and } \\
\text { working-class residents } \\
\text { on council estates, North } \\
\text { Bermondsey (UK) }\end{array}$ \\
\hline Conflict/competition & $\begin{array}{l}\text { Arabs and } \\
\text { Hungarian } \\
\text { shopkeepers in } \\
\text { Józsefváros (HU) }\end{array}$ & $\begin{array}{l}\text { Tourists and } \\
\text { residents in } \\
\text { Sagrada Família } \\
\text { (SPA) }\end{array}$ & $\begin{array}{l}\text { New Turkish residents } \\
\text { and old German and } \\
\text { Turkish residents in } \\
\text { MAN's housing stock in } \\
\text { Werderau (GE) }\end{array}$ \\
\hline
\end{tabular}

behaviours and actual relations (what people actually do) (Table 1). More precisely, although aware of the over-simplification, we consider three types of relations (cooperation, lack of contact, conflict), and three types of representations (positive, neutral/indifferent, negative). A caveat, perhaps obvious, is that the schematic representation provided below is static, whereas in reality circular dynamics are constantly operating by which representations are shaped by social interactions, which in turn affect representations.

The first interesting point reflected by the presented evidence is that the market seems to have the capacity to foster competition as well as cooperation and to produce unusual matches of representations and interactions. Collaboration develops even between groups with reciprocal negative representations as a consequence of economic rationales. For example, Chinese traders in the Four Tigers Market in Józsefváros employ Roma people because they constitute cheap manpower even though they complain about their attitude towards work. On the other hand, groups who carry reciprocal positive representations may compete, as in the case of Arab shopkeepers who are regarded as fair competitors by their Hungarian peers, in spite of their sometimes ruthless practices, including, for instance, buying many shops solely to keep them closed and thus secure the area from commercial rivals.

Sometimes, relations developed in the labour market and in estates overlap, as in the case of elderly Hungarian baby-sitters hired by Chinese families in Taraliget Residential Park. Having very little time to look after their children due to their intensive work pace, Asian immigrants often hire retired Hungarian women to baby-sit their children. These women who also live in the neighbourhood often take care of their own grandchildren and of Chinese children at the same time. In this 
case, children play a key role in creating more personal social relations between the two groups, as the economic dimension gradually loses importance and these women become almost like distant relatives.

This was the only example among the investigated Hungarian sites where small signs of cooperation are not matched with negative representations. One could hypothesize that such scarcity of cooperative interethnic behaviours in the case of Budapest neighbourhoods is related to the strongly xenophobic discourse propagated in Hungarian politics by parties such as Jobbik. Such a hypothesis, however, has not been explicitly corroborated by local fieldwork and would need supplementary targeted research to be formulated more precisely.

Among 'outsiders' migrants are not always the most evident or significant subjects or objects of neighbourhood conflicts. In Sagrada Família, for instance, the main concern of residents and the focus of their protests towards local authorities are city-users, i.e. the crowds of tourists flooding the neighbourhood and hampering its everyday life.

Finally, it is worth remembering that actual relations are also contingent on time. This means that different groups may interact well during the day but not at night, as is often the case in public gardens or commercial areas. For instance, in Via di Nanni in San Paolo the open market offers an opportunity for amiable contact between majority (especially elderly) and minority residents during the morning whereas at night the emptied area becomes a car park and the few existing bars attract single migrant men who are regarded as disturbing and even dangerous by elderly people. ${ }^{2}$

To conclude on this point, we can maintain that different types of inter-group relations can be found not just in the same city but also within the same neighbourhood, according to site and time. Inter-group relations are not given, they are played out in concrete situations by the actors in the field and are influenced by factors related to multiple levels: the nation, the city, the neighbourhood, the single site of interaction, the situation.

\section{The Role of Places in Boundary-Making and Inter-Group Relations}

The concept of place in geography and urban sociology emphasizes the relations between subjective and objective perspectives since it encompasses both space and the experience that gives space an identity; in distinction to space, place also refers to memories, identities and relations (Abrahamson 1996; Soja and Hooper 1993; Greif and Cruiz 1997). We can then say that places are social constructions too, like group boundaries, and that both are objects of making-work. Furthermore, processes of place-making and group-making are related. As Amin (2012) underlines,

\footnotetext{
${ }^{2}$ See http://www.concordiadiscors.eu/assets/Turin-final-report_integrated_12_10_2012-1.pdf
} 
everyday encounters and interactions construct and, at the same time, are shaped by urban habitat, understood as the assembly of technologies, built environment and layout of public spaces, infrastructures and services, rules of order and symbolic culture.

In this perspective, public places - defined as 'places accessible to the public' play a crucial role since they can be regarded as the main element from which people derive their representations of cities and neighbourhoods (Tonnelat 2010; Lynch 1960). They are the places where urban representation and sociality are displayed and built at the same time (Amin 2012; Massey 2005). For these reasons, in our analysis we have given special attention to public places and most of the 'sites of interaction' where ethnographic work was carried out belong to this category.

The second assumption on which we based our analysis is that every place comes with its embedded set of principles of public organization and order, permissibility and possibilities, and terms of engagement between subjects (Amin 2012). Whereas public places are 'the world in the streets where one meets strangers', (Wessendorf 2010, p. 22), 'micropublics', as defined by Amin (2002) are spaces of associations where habit of practice replaces mere co-presence, and dialogue and 'prosaic negotiations' are compulsory; they are similar to what Wood and Landry (2007) define as 'zones of encounter', i.e. places where deeper and more enduring interactions between people engaging in shared activities and common goals can take place, such as housing associations, parents' groups, schools, workplaces, youth centres, sport clubs, etc. Therefore, despite the prevalent attention given to public places, in this research book we have tried to analyze inter-group relations also in 'micropublics' as well as in housing estates and apartment buildings, starting from the hypothesis that the different characteristics of these places foster the development of different kinds of relations (Wessendorf 2010).

Finally, in addition to being zones of encounters, places can simultaneously be stakes of conflict. In particular, places can be viewed as stakes both in material and in symbolical terms since conflict over them can hinge upon the feeling and 'right to belong', beliefs and values, social norms of behaviours and lifestyles. The construction of ethnic categories is shaped by local struggles for material and symbolic resources (housing, jobs, public places) which sometimes take an ethnic form and may interplay with social divisions of gender, class and age (Ray et al. 2008; Esser 2002). Furthermore, when looking at urban places as stakes of conflict, we have also to consider that the urban infrastructure and building environment impact processes in which resources and opportunities are allocated. Urban investment defines how much spaces, activities and people count and reflect the decision to recognize and accommodate certain demands and claimants and disregard others (Amin 2012; Subiròs 2011).

As Wimmer (2013) underlines, it would make little sense to debate whether ethnicity is mostly about interests and material benefits or identities and immaterial goods since ethnic boundary-making intersects these different levels and mobilizes both sets of resources. For the sake of clarity, however, in the next sections we will analyze the two spheres separately. 


\subsection{Places as Material Stakes for (Ethnic) Conflict}

The nature of place as a stake of conflict is evident when we consider housing estates. Housing constitutes a key determinant for immigration settlement at the local level and it is one of the fundamental urban social goods over which conflict can be staged. As studies have shown (Dench et al. 2006; Ray et al. 2008), allocation of social housing often becomes a key issue around which ethnic resentment may coalesce by distinguishing the deserving from the undeserving and thereby activating a sense of entitlement grounded in length of stay and sets of moral values.

This is particularly evident in neighbourhoods where access to housing stock suddenly changed, such as Bermondsey and Werderau. In post-World War 2 Bermondsey, the vast majority of housing stock was social housing, primarily controlled by the Bermondsey Metropolitan Borough. Under a principle informally known as 'sons and daughters', housing units would first and foremost be made available to the offspring of tenants who already lived in the borough. The structural reform of 1965 that saw the metropolitan councils of Bermondsey, Southwark and Camberwell amalgamated into the London Borough of Southwark meant that the social housing stock in Bermondsey became available to residents from other parts of Southwark. Furthermore, the allocation of social housing became needs-based, conditional upon an assessment of personal circumstances rather than local family links. Thus from the early 1970s, immigrants and ethnic minorities increasingly gained access to social housing. At the same time, the social housing stock began to decline due to the introduction of the right to buy in 1980, while demand for the decreasing stock increased. Since new residents often belong to minorities, this situation has raised conflicts which often run along ethnic lines or at least are framed in such a way by old residents belonging to the white working class.

A similar situation occurred in Werderau where most of the inhabitants worked for the nearby MAN factory and lived in housing stock owned by the same company. With the arrival of wives and children of guest workers in the late 1960s and 1970s, sizeable numbers of these reunited families, mostly of Turkish origin, moved to Werderau and quickly integrated into the neighbourhood life centred on the factory. In 1998 MAN sold the housing stock to the real estate company Telos, which soon after went bankrupt (in 2001). This triggered a series of ownership changes among different investors and, as a result, new tenants and new house owners, mainly migrants of Turkish origin, moved into the neighbourhood. In contrast to past waves of local migration, in the new context of uncertainty this change has produced divisions between old and new residents, with tensions growing between German and Turkish residents, as well as between old and new Turkish inhabitants. Although the origin of the conflict seems clearly rooted in competition for control over housing stock, it has been framed by residents predominantly as an ethnic and cultural conflict, given that the new residents are largely Turkish and perceived as having different norms of behaviour. As a matter of fact, this conflict has partially been weakened by the intervention of the Municipality on the material set of interests by 
the acquisition of part of the housing stock by a city non-profit housing company in order to partially restore the residents' control and the pursuit of public well-being in the management.

Therefore conflicts over places are not necessarily framed as such and can turn into ethnic conflicts especially when length of stay and ethnic belonging overlap. When such ethnic and cultural tensions hide material conflicts, these can often be managed and partially overcome, as in Werderau, by changing the set of interests.

\subsection{Places as Symbolic Stakes: Ethnic Tensions in Post- Industrial Neighbourhoods}

The kind of conflict illustrated above between long-established mainly native working-class residents and newly settled ethnic minorities seems to depend not only on housing-related interests, but also on more general socio-economic trends. In fact, the ways in which groups position themselves and sometimes collide are also grounded in the everyday material realities of living in a declining urban neighbourhood.

In these neighbourhoods, narratives of longstanding residents reflect material changes caused by economic decline and convey a sense of symbolic loss, embodied in nostalgia for the allegedly cohesive community of the past. This negative epic is often related with stories about ethnic difference and constructions of majority and minorities are deployed to manage material and symbolic fears and conflicts over scarce resources and space (Ray et al. 2008; Fenton and Mann 2006; Watt 2006).

In a situation of longstanding and apparently overwhelming downward urban and social mobility caused by the end of Fordism and the inability to find alternative social and economic organizational settings, there seems to be a higher likelihood of decline becoming racialized. Body-Gendrot (2002), for instance, highlights that in French banlieues the clash of ethnic cultures is being exacerbated by the threat of downward mobility experienced by white working class families, the stigma attached to these areas and the decay of the physical landscape. According to the French author, the areas which have suffered the most are the ones locked - like some of our target neighbourhoods - to the Fordist system since they appear to be too functionally designed to be able to adapt to the economic and social changes. The structural changes, loss of status and downward mobility experienced by bluecollar workers thus nurture racist attitudes which find root in the decomposition of the working class (Body-Gendrot 2002). As Lamont (2000) underlines, in this postindustrial society the idea of social success may appear particularly unreachable to the working class compared to other social classes, as their living standards are undergoing a process of steady decline.

As a matter of fact, we found conflicts between older working-class residents (predominantly native but sometimes with a background of internal or international 
migration) and newly settled ethnic minorities in those former industrial neighbourhoods (Bermondsey, Werderau, Barriera di Milano) which are facing difficulties in the transition to a new economic and social landscape and whose collective identities appear trapped in a glorious but obsolete past. Older working-class residents feel that both their material well-being and their identity and sense of worth are threatened and they find it difficult to identify how this situation can be successfully overcome.

Whereas in most of the post-industrial neighbourhoods described in previous chapters, ethnic minorities are regarded by the majority as a factor of decline, in other investigated neighbourhoods, diversity is viewed as a positive asset. This more positive attitude seems to be related to the ability of neighbourhoods to cope with new global economic and social trends which are often associated with the increasing presence of 'new middle-class multiculturals' (Simon 2005), i.e. middle-class professionals and cultural workers, usually with a high level of civic engagement. ${ }^{3}$ This is the case in Camberwell and Gostenhof where middle-class multiculturals are rather rooted, as well as in Poble Sec and San Paolo, traditional working-class neighbourhoods now shifting towards a more mixed social composition thanks to economic reconversion and urban renewal processes.

In Camberwell, gentrification, like ethnic diversity, is long-established, and the earlier waves of gentrifiers, most of whom belong to a multicultural middleclass which regards diversity as one of the appeals of the area, are committed to the neighbourhood.

In Gostenhof, during the last ten years, extensive renovation works were initiated in order to improve the quality of living and the image of the neighbourhood which, although still socially challenged, has developed a positive reputation for being a multicultural and 'artistic' area. The result is that in Gostenhof there is a cosmopolitan atmosphere and, as in Camberwell, many inhabitants are actively engaged in voluntary work in the neighbourhood. The numerous international Delikatessen shops, which reflect the diverse ethnic backgrounds of the residents, play a meaningful role in the lives of Gostenhof's residents and also attract people from other city areas as places to meet, interact and spend leisure time. The diverse social and ethnic composition is perceived as a key characteristic of the neighbourhood and most of the people interviewed, as well as the media, emphasized the high level of acceptance of, and even desire for, diversity.

A similar process seems to be occurring in Poble Sec which has been undergoing a process of change during recent years which has seen a few streets become an important location in the city's 'bohemian' leisure and nightlife scene. Although it is mainly a working-class neighbourhood with lower than average real estate prices, during the last decade Poble Sec has also attracted some young middle class residents and the neighbourhood's increasing - and increasingly appreciated diversity is also the product of this process. Similarly, in San Paolo, another of our investigated neighbourhoods where diversity is generally valued, in the 1990s work

\footnotetext{
${ }^{3}$ In fact, there is evidence that people in higher socio-cultural positions are more likely to take part in civic associations ( $\mathrm{Li}$ et al. 2003).
} 
started on tearing down abandoned industrial buildings and converting them into residential units, commercial outfits (shopping malls), public services and infrastructures, and cultural sites. Furthermore, in contrast to Barriera di Milano - where post-industrial urban regeneration is just beginning and the socio-economic impact of de-industrialization has become heavier and heavier over the last two decades the socio-economic profile of San Paolo-Cenisia is not particularly worrying and, in some respects, even better than the city average (due, for instance, to higher than average education levels), thereby confirming its capacity to move beyond Fordism.

To sum up, the likelihood of conflict development along ethnic lines seems to depend more on patterns of socio-economic mobility, whether improving or declining, of the long-established majority than on their socio-economic status per se and, when specifically referring to post-industrial neighbourhoods, on their overall ability to reinvent and emancipate themselves from the rigidities of the Fordist economic and social model.

\subsection{Places as 'Connecting Opportunities': Is Integration Transferable?}

Places can be conceived, beyond stakes, as 'connecting opportunities' which offer the chance to meet and know the 'Other'. As we have maintained, they are not just containers: they are embedded with identities and rules which shape the encounters and relations occurring within them and, conversely, are themselves shaped by these relations.

In the investigated neighbourhoods, we found that the lack of 'connecting opportunities' (e.g. meeting places, venues for organized activities, etc.) tended to generate a fragmented social fabric and less cooperative inter-group relations. We must, however, consider that the viability of connecting places is not simply a matter of how many such places are in a given neighbourhood. Certainly, neighbourhoods such as Barriera di Milano, Werderau, Kőbánya and Sagrada Família have few public gardens, squares, centres and associations compared to the other target neighbourhoods. Despite this scarcity, the available areas, such as public greens in Kőbánya or Sempione Park in Barriera, are neglected since they are not properly equipped and are regarded as unsafe. In contrast, the well-equipped Tres Xemeneies park which borders Poble Sec and Ruffini Park which borders San Paolo are used intensively by residents and compensate for the lack of large green areas within these two neighbourhoods. It is therefore evident that meeting places, being socially produced, cannot be measured only in terms of square metres but also of concrete use and experience.

Furthermore, the symbolic values of places make them arenas where moral order is displayed and boundaries between 'us' and 'them' are constantly in the making. In this regard, Ray, Hudson and Phillips (2008) point out how racialized narratives of neighbourhood decline may be expressed through the affirmation of the moral 
superiority of 'we' who care and keep the environment clean and 'they' who do not. Similarly, Wimmer (2004) highlights that the use of places often reflects or is employed for exemplifying a sort of moral order. According to him, the discourse of order does not represent a hidden way of excluding groups on an ethnic basis, but rather, a pure logic of boundary-making. As a matter of fact, in the Swiss neighbourhoods that Wimmer investigated, exclusionary sentiments and discourses were not directed towards immigrants per se but towards outsiders seen as undermining the established social and cultural order. In that case, immigrant residents were regarded as belonging to the 'us' or not depending on whether they were seen as complying with the rule of order and keeping common and public places tidy. Therefore, antimigrant attitudes may be nourished by the feeling of loss of social order often reflected in migrants' use of places according to different and unfamiliar rules.

In this regard, an episode that happened in San Paolo is particularly enlightening. Here, groups of Peruvians used the volleyball field of the SPA gardens until late at night listening to music and speaking loudly, raising complaints from people living nearby. Then meetings aimed at defusing the tensions were organized with the support of the District administration. Surprisingly, the more inflexible positions were held by long-established Peruvians residents who - as they themselves admitted were in favour of the implementation of strict rules whereas native residents were more open to negotiation and compromise. The conflict was finally solved thanks not just to rules being agreed for the use of this place, but also to a light re-planning which made it possible to move the fields farther from the apartment buildings. This episode confirms Wimmer's view that conflict does not necessarily express latent racist attitudes but may actually just be about accepting the established local order.

A specific lesson from our case studies in the city chapters is that the connecting potential of public places also depends on rules of use, the absence or ineffectiveness of which can generate conflicts quickly turning into 'moral clashes' along ethnic lines. From our fieldwork, we can derive some hypotheses on how to improve the effectiveness of site-specific sets of rules. In the first place, these rules can be partially embedded in spaces. Indeed, sometimes the very setting of the place suggests the ways in which it should be used thereby limiting negotiation and preventing conflicts; in other cases, places are very open to different uses and the agreement on them is completely delegated to users who could be unable to find a satisfying arrangement. If the first option tends to limit conflicts, overly neat distinctions between areas designed for specific purposes can also limit contacts. For instance, in the SPA gardens in San Paolo or the Tres Xemenies Park in Poble Sec specialized areas (a skateboarding area and basket or football fields for adolescents, playgrounds for children, benches for elderly people, etc.) certainly prevent conflicts but also seem to prevent meaningful interactions since each group uses a specific area without contacts with others.

This sort of space planning conducive to inter-group encounters should not, however, be seen as something mechanical or deterministic and it can also be the object of negotiation, as in the case of SPA gardens in San Paolo mentioned above.

The second element which can help to identify common rules of use for places is formal or informal mediation facilitated by organized actors such as associations, 
open market organizations, housing associations, etc. In fact, several authors who have investigated interactions in urban places have underlined the crucial importance of the intermediation of third parties (Amin 2010, 2012; Wood and Landry 2007; Sandercock 2003). For instance, in our case studies from the investigated London estates, tenants' and residents' associations (TRAs) - elected bodies that manage social activities on estates and dialogue with service providers - seem to soften potential conflicts among residents. In Montanaro Gardens in Barriera di Milano, conflicts are often solved thanks to a social cooperative that employs mentally ill persons in tasks such as gardening, cleaning the park and organizing children's activities. Mothers, both native and foreign, entrust them to oversee their children while they play and elderly persons turn to this group for help when problems arise over park use. The neutral position of this group, being anomalous and eccentric with regard to established social order, makes it a very useful tool for conflict resolution.

The relevance of both rules of use and mediating action is also evident in the case of Langwasser where the opening of an Intercultural Garden raised fears and protests among the resident population. In that case, the mediating role of the Municipality was generally very important in overcoming the conflict, but in practical terms the key development was the capacity of the locally established Intercultural Garden committee to counter anxieties and concerns by developing a set of rules to regulate opening hours, hygiene and garbage, parking and all other practical issues that could potentially generate disturbance for the neighbours. It is worth underlining that this brokerage role can be assumed formally in the organization's mission, as in Langwasser, or informally, as in the other cases described above.

Inflows of neighbourhood users attracted by leisure opportunities or touristic sites have an ambivalent effect as they may either foster or hamper the use of public places as connecting opportunities by residents. In Sagrada Família public places and facilities are perceived as being totally overwhelmed by tourists. Most shops and bars cater to them rather than to residents who as a result have few places to meet. According to some residents, the flea market in Encants Vells (at the border of Sagrada Família), also attracts a lot of outsiders and is therefore not used as a meeting area by neighbours. Also in Józsefváros, a centrally-located neighbourhood and one of the most congested districts of Budapest, the crowds of tourists seem to hamper contacts and relations among residents despite the existence of a multitude of meeting places.

On the contrary, in the inner neighbourhood of Gostenhof the high population density and the increasing number of shops and restaurants are perceived by interviewees to have fostered a trend away from mutual ignorance towards greater harmony and cooperation among residents: the everyday interactions involved in activities such as shopping, leisure time pursuits, courtyard festivals as well as participation in associations, the local district committee, and neighbourhood centres are considered crucial in fostering encounters between migrants and natives. Similarly, in Camberwell the high density of restaurants, cafés and shops is predominantly perceived as an asset for inter-group relations. To take one last example, in Poble Sec the transformation of Blai Street into a pedestrian street and other 
urban transformations have attracted people from outside the neighbourhood thereby increasing, according to the residents, positive interactions across cultural, social and origin cleavages.

Finally, in all investigated neighbourhoods, cooperation is generally easier in what Wood and Landry (2007) call 'zones of encounter' and Amin (2002) defines 'micropublic', where deeper and more enduring interactions between people engaging in shared activities and common goals can take place. Such places are, for instance, associations, schools, youth centres, sport clubs, etc. This is exemplified in the case of 'Laboratorio Territoriale', managed by the municipal administration in San Paolo, which houses the internet point together with the headquarters of several native and migrant associations. Here the social and cultural heterogeneity of the users is not a cause of conflict, but rather, a starting point for positive and even cooperative interactions. The Public Baths of Aglié Street in Barriera di Milano work in a similar way: here friendly relations and cooperation clearly prevail over conflict. The Sagrada Família multi-purpose centre where a library, civic centre, local marketplace, social services, and organizations' premises are located and where activities (e.g. Chinese New Year's celebrations) and courses are organized, generates opportunities of encounter between immigrants and natives that allow positive everyday interactions, albeit often superficial. In Langwasser, the Intercultural Gardens - which are gardens with no fences between neighbours in order to facilitate encounters and foster mutual tolerance and respect - bring together migrants of different origins and natives through the shared activity of gardening. These kinds of examples are actually rather numerous and cannot be listed in full here (for further examples see the Concordia Discors project's city reports on www. concordiadiscors.eu).

The potential of these places to facilitate positive interactions is hard to deny. These are places where rules about the use of the space are usually clear and often codified, and where collective actors with explicit or implicit mediating functions are present: two factors that, as outlined above, facilitate positive group interactions. Furthermore, these places are usually selective, i.e. users go there with specific purposes and sometimes share similar lifestyles and even values, all of which also makes the development of contacts and positive inter-group relations easier.

What is less obvious is that the integration (essentially understood here as peaceful and even cooperative interethnic coexistence) achieved in these places is not completely transferable to the rest of the neighbourhood. Often the same groups develop different relations in different places. They may cooperate in schools, ignore each other in public gardens, and maybe even fight in apartment buildings. For instance, in Bermondsey majority and minority groups may meet and positively interact in the public library but ignore each other in Dickens Estates. In San Paolo, elderly people and migrant men may get on well together in SPA gardens and confront each other with apprehension in via Di Nanni at night. These examples illustrate that although these 'zones of encounters' are crucial to fostering positive inter-group relations, the integration produced within them will not spontaneously expand beyond them. In order to enhance their positive impact on neighbourhood 
sociability, specific measures are needed. Otherwise, they risk becoming little 'pacific' isles of integration, where many occasionally visit but few settle for good.

\section{Policy Community Cohesion as a Factor of Narrative Autonomy}

As we explained in the Introduction, although the core of the book consists in the analysis of inter-group boundaries and relations in everyday life, we have also analyzed the macro-frames within which everyday relations and narratives are developed, with special attention to neighbourhood policy communities and local media, as well as the relation between these two actors. As illustrated across the city-centred chapters, neighbourhood policy communities - meaning all actors involved in local policymaking regardless of their legal status, i.e. public, no-profit and profit actors (Jordan 1990; Rhodes 1990; Marsh and Rhodes 1992) - play a role in shaping local "imagined communities" ${ }^{4}$ by contributing to the production of 'cultural repertoires' that define what makes one part of the local community (Lamont 2000). Such cultural toolkits help shape the notions of citizenship and identity that determine which perceptions of relations between immigrants and majority are considered sensible, realistic and legitimate, and which collective identities and demands are more likely to gain legitimacy in public discourse (Koopmans et al. 2005). In other words, policy communities hold what Bourdieu (1985) defines as symbolic capital, i.e. 'autonomy of the field of symbolic production' (p. 731). Indeed, he writes, 'politics is the site par excellence of symbolic efficacy, the action that is performed through signs capable of producing social things and, in particular, groups' (p. 741), it is the site arena where the power of narrative, of conserving or transforming the categories through which the world is perceived is displayed.

As Andrea Pogliano points out in the chapter on media, this symbolic power seems to be greater in neighbourhoods with more cohesive policy communities. Here we mean cohesion both in terms of the degree of consistency among different actors' representations and of the operational coordination among them. This is a very important point that we would like to develop further here. Our comparative inquiry suggests that, throughout very different urban contexts, more cohesive local policy communities appear more resilient to the exogenous influences of city-level or national media and/or political movements and better able to produce selfrepresentations of the local community. Given that exogenous narratives are often broadly critical towards migration, such narrative autonomy is often synonymous with community resilience towards xenophobic thinking and practices.

To give a concrete example, we can point at the prevalent 'stories about the neighbourhood' of San Paolo-Cenisia proliferating in local media which are very

\footnotetext{
4 'Imagined community' (Anderson 1991) can be meant as symbolic communities whose members share categorisation systems to differentiate insiders and outsiders and common vocabularies through which they create common identities (Gusfield 1975).
} 
different from those in Barriera di Milano. The former are strongly permeated with references to the neighbourhood's history of anti-fascist insurgency and workers' struggles. The neighbourhood is still systematically described as a working-class district, characterized by a strong solidarity towards immigrants from other Italian regions in 1950s-1960s and from abroad nowadays. It is worth also noting that in this case the sources more frequently used by journalists to write about the neighbourhood are usually the neighbourhood's stakeholders (District councillors, NGOs, service providers, etc), i.e. actors who belong to the local policy community. On the other hand, in the case of Barriera di Milano, a collection of brief comments from bystanders - who describe the neighbourhood as a 'problem area', 'robbery district', 'neighbourhood with many illegal immigrants', 'unsafe place', and 'slum' - is often the journalistic solution to the scarcity of strong and consistent local voices. Our hypothesis to make sense of such striking difference is that in San Paolo-Cenisia the presence of strong stakeholders and a well-organized policy community helps to give voice to the neighbourhood and to generate and channel positive narratives about inter-group relations. As Simon (2000) argues in his analysis of Belleville, a highly diverse Paris neighbourhood, the working-class past of the neighbourhood and the longstanding immigrant presence are historical facts but they probably had neither the impact nor the importance which is now attributed to them in narratives of the neighbourhood. So in the case of Belleville narratives are also of great importance in shaping today's inter-group relations: by associating them with the neighbourhood's collective memory, immigrants cease to be unfamiliar and potentially threatening outsiders.

In the same way, the more positive framing of policy interventions in Poble Sec can be seen as the result of a very rich network of associations fostering a dynamic civic and social life. In promoting such strong neighbourhood activism an important role has been played by the Pla de Desenvolupament Comunitari del Poble Sec (Communitarian Development Plan), a project created in 2005 and led by the Coordinadora d'Entitats del Poble Sec (Coordination of the neighbourhood's associations) with the support of the Taula de Convivència del Poble Sec (Table for Peaceful Coexistence in Poble Sec) set up by the local administration. In contrast, in Sagrada Família there are many associations, but just a few residents participate in their activities so they are not as strong as in Poble Sec.

Elaborating further on what is implicit in Pogliano's analysis, in Werderau the mobilization of conflict is mirrored in the intensification of media coverage. Looking at the distribution of articles dealing with migrants over time, it is remarkable that there was a sudden rise of such articles in 2002, corresponding with a wave of moral panic, followed by a rapid fall: in the next year only three out of 13 articles explicitly touched upon the issue. This development seems to be a result both of the broader political change in the City of Nuremberg and of the appointment in Werderau of a district coordinator who mobilized the local policy community and put pressure on the local media. ${ }^{5}$ In Langwasser this influence was even more explicit: the framing

\footnotetext{
${ }^{5}$ The case of Werderau demonstrates how institutional changes may have consequences for the structure of public discourse and vice versa (Koopmans et al. 2005).
} 
of the conflict over the Intercultural Gardens as a migrant minority-majority conflict had strongly emotionalized and politicized the debate and had drawn more people into it. In this situation the district coordinator appealed to the media not to give the anti-immigrant groups publicity and support for their propaganda. The media therefore became increasingly critical of the right-wing campaign and covered the project more favourably.

The cases of Werderau and Langwasser clearly show also how a cohesive local policy community can reject anti-immigrant political campaigns organized by external actors. In Werderau, the ethnicization of the conflict was indeed partly stimulated by the nativist, right-wing forces of the neo-Nazi party NPD and 'Ausländerstopp', a regional group coming from outside, which in both municipal and federal elections obtained better electoral results in Werderau than elsewhere in the city. In Langwasser fears about the Intercultural Gardens were also reinforced by the anti-immigrant agitation of right-wing groups. After the intervention of the City-appointed community workers and a change of perspective in the media, the opposition campaigns slowly weakened.

Similar although less evident dynamics were registered in Bermondsey. Events to celebrate St. George's Day have been staged in different parts of northern Southwark since 2006. The celebrations have, particularly in South Bermondsey, been framed as part of an effort to 'reclaim' St George (whose cross is on the English flag) from the anti-immigrant British National Party and the National Front, both of which had used the area around The Blue to stage marches. ${ }^{6}$ By mobilizing and networking the neighbourhood civil society organizations and schools, it appears that Southwark Borough has been successful in re-claiming St. George's Day as this is now a community celebration rather than a stage for BNP demonstrations. This saint's day now brings together the local community around the celebration of the English flag meant as the symbol of a mixed British society rather than a white-only one.

The British and, especially, the German cases are particularly revealing about the role of what Brubaker $(2002$, 2006) calls 'ethno-political entrepreneurs'. The American author points out how dramatic events can crystallize a potential group so that undertaking a strategy of provocation, often by a very small number of persons, can sometimes be an effective strategy of group-making. ${ }^{7}$ In this case, the protagonists of ethnic conflicts are not ethnic groups as such but various kinds of organizations including institutions, political parties, associations and movements, and mass media, all of which compete for the right to represent the same (putative) group. Furthermore, these dynamics highlight that claim-making and conflicts are

\footnotetext{
${ }^{6}$ See the following thread with views from local residents concerning the BNP and different experiences of racism and multiculture in Bermondsey: http://www.london-se1.co.uk/forum/ $\mathrm{read} / 1 / 61972$ (accessed 18.04.2012).

${ }^{7}$ Conflict can then be both the cause and the consequence of a high level of 'groupness' (Brubaker 2002, 2006)
} 
interactive processes, confirming once again that ethnic conflict is often far from being rooted in actual cultural differences ${ }^{8}$ (Koopmans et al. 2005).

This does not mean that the conflict does not exist but, as the German cases clearly show, it may assume the form of 'meta-conflict' or 'conflict over the nature of conflict' (Horowitz 1991), a struggle over the framing and narrative used to label and explain the conflict. As we said at the beginning of this section, the symbolic capital held by neighbourhood policy communities gives them a role in this process. We can thus conclude that the ability of any given local policy community to construct its own narrative is crucial to making a neighbourhood resilient against disruptive external narratives and thus to building a more cohesive local society.

\section{A Wider Look: Integration as a Threatened Local Public Good}

After more than half a decade since its outburst, all indicators show us that the current economic crisis is burdening and weakening the social fabric of European cities, albeit not in an even way. Even if there are significant local variations, the recession is everywhere eroding the primary economic and political foundations of integration, namely, a sufficient degree of labour market inclusion of immigrant workers and a sustainable (or perceived as such by the autochthonous majority) level of welfare consumption by those workers and their families. At the same time, spontaneous shock-absorbing mechanisms - among which one could include migrant returns and secondary migration to other, more promising, destinations are operating only to a limited, though hard to measure, extent.

In this context, the public budget crisis is dramatically reducing (although here too in a very asymmetrical way across Europe) the states' capacity to address gaps in integration through targeted policy programmes and measures. Local authorities are increasingly being left alone to face the social consequences of the crisis and, in particular, its impact on the integration between foreign immigrants and the receiving society. But local authorities are themselves in deep financial difficulties, and integration policies are often the first casualty of spending reviews and cuts. This is especially true in southern Europe, where the transfer of finances from central states and regions to municipal authorities is being subjected to particularly heavy budget cuts.

In such a bleak overall context, one could hypothesize that immediate repercussions would be felt at the local level, including on social ties and inter-group

\footnotetext{
${ }^{8}$ Wimmer reminds us that group closure ('groupness') and clarity of boundaries ('boundedness') may vary in degree from one social situation or institutional context to another. Therefore, the stability of boundaries may vary and some ethnic boundaries are more resistant to strategic reinterpretation than others: thick identities reduce the range of strategic options that actors have at their disposal, while where boundaries are not salient, classification ambiguity and complexity is high and boundary shift for strategic purpose is easier (Wimmer 2008).
} 
dynamics at the neighbourhood and street level. As in other historical periods marked by trends of societal impoverishment and growing inequality, one could hypothesize that neighbourhood communities would emerge as the first level where gaps in integration manifest themselves, generating tensions which are easily framed as interethnic. One could expect, and fear, that, due, among other factors, to the apparently harshening socio-economic stratification of housing markets, such ethnically framed neighbourhood conflicts would increasingly resemble 'wars among poors'.

Such hypotheses and expectations are certainly legitimate in the current European circumstances. And they indeed stood prominently among the initial empirical research questions for the comparative project presented in this book. At the end of our fieldwork, though, we have to revise these initial hypotheses, at least in part. Worries and complaints about the impact of the crisis were, of course, voiced in our research fields, for instance by local policymakers or bureaucrats having to cope with budget reductions, but in a less pervasive and insistent way than we expected. Above all, in none of our target neighbourhoods did crisis-related anxiety seem to crystallize into explicit and widespread immigrant and/or minority scapegoating capable of providing cheap combustible for interethnic conflict.

Given the overall, highly uneven European geography of the impact of the crisis, such apparent lack of clearly crisis-related interethnic tensions is particularly striking in the case of Barcelona. This unexpected negative finding is consistent, however, with available broader evidence on the impact of the crisis on immigrant integration and native-immigrant relations in crisis-stricken Spain. As a matter of fact, several researchers have pointed out, often with a mix of surprise and relief, the lack of xenophobic reactions even in the context of the ever harsher competition in the lower layers of the Spanish labour market (Arango 2013; Rinken and Velasco Dujo 2010; Rinken 2011). How to explain such a puzzling and mildly reassuring outcome? Based on the evidence presented in the chapter on Barcelona, a few hypotheses can be formulated. One could, perhaps, argue that we were lucky, or maybe biased, in the selection of the target cities and neighbourhoods: if fieldwork had been carried out, for instance, in a city like Athens, a worsening in inter-group relations associated with the crisis would almost certainly have emerged. But, in the meantime, one has to acknowledge that some of the researched neighbourhoods - in Turin, Barcelona or Budapest, to mention only the most evident cases - are far from immune to the negative impacts of the crisis on prosperity, equality and security. So, we have to consider other possible explanations for the relatively reassuring lack of spectacular findings in terms of crisis-related interethnic conflict.

A possible factor could have to do with timing and, more specifically, with the length of time that is generally needed before financial and macroeconomic downturns produce occupational and social repercussions, and then before these trigger the processes of social construction of ethnic conflict that have been analytically described by Claudia Köhler in her chapter.

The time factor is certainly influential, and the landscape of inter-group relations might indeed look worse if we return to our research fields in 1 or 2 years, especially if glimmers of economic recovery remain so few and so weak. But we cannot rule 
out another, less pessimistic, explanation for the relatively peaceful outlook that was revealed by our case studies: that there is a sort of intrinsic resilience within neighbourhood societies facing potentially disrupting pressures. As delineated in the previous paragraph, we understand the capacity of local policy communities to maintain control over the image of their neighbourhood in the media and in the broader public sphere, and to resist and counter potentially harmful exogenous narratives, to be a key attribute and an important corollary of community cohesion.

In presenting the results of research which was also supported by the Integration Fund of the European Union, we believe it is appropriate to conclude by trying to draw some additional conclusions with specific regard to the concept of integration from the arguments above. Research carried out in rapidly evolving, sometimes unquestionably fragile but nevertheless resilient neighbourhoods, suggests to us that, in contemporary European cities, the integration of immigrants (especially in its relational dimension, which primarily consists of the absence of grassroots ethnic conflict) can fruitfully be conceived as a local public good. A 'public good' because integration, if rigorously understood as a two-way process, can indeed be argued to be a non-excludable and non-rivalrous good (i.e. the two key requisites according to the standard micro-economic definition of public goods). But it is also a 'local good', in the sense that successful integration in today's immigration neighbourhoods can hardly be achieved without a strong, diffuse and proactive engagement of local communities themselves.

If integration had ever been something which could be imported (which is highly questionable), produced at national level and locally distributed from above, this is not the case anymore. In US society, where the degree of collective reliance on the role of the state as an 'integration/cohesion provider' is historically lower than in Europe, the importance of grassroots community building (and more recently 'community organizing', as a distinct and more politically aware form of mobilization) for societal cohesion is traditionally greater and better understood. The comparative research carried out in European neighbourhoods that we have presented in this book suggests to us that it is time for Europe to learn from that tradition, avoiding, however, any naïve illusion of a quick and easy socio-cultural transplant. Indeed, we must be aware that European societies are deeply different from North American ones and we cannot expect a sudden change in attitudes, ideas and values built and consolidated over centuries. Furthermore, community activism requires structural conditions starting from what we called 'interaction sites' where cross-cultural groups have the chance to form and strengthen themselves. But it is precisely these interaction sites - such as public libraries, public parks, NGOs' premises, and other similar places of potential encounter - that are now at particularly high risk of disappearance, due to the sharp retreat of public actors.

Cautious voices, warning, for instance, that deprived, and sometimes conflicted, neighbourhoods might not be conducive to community involvement and partnership (Salmon 2002), should not be ignored. Nevertheless, we still believe that without a more direct, intensive and continuous engagement of local communities, with neighbourhoods as a pivotal level for both analysis and mobilization, integration is probably destined to become an ever more elusive reality. 
Open Access This chapter is distributed under the terms of the Creative Commons AttributionNoncommercial 2.5 License (http://creativecommons.org/licenses/by-nc/2.5/) which permits any noncommercial use, distribution, and reproduction in any medium, provided the original author(s) and source are credited.

The images or other third party material in this chapter are included in the work's Creative Commons license, unless indicated otherwise in the credit line; if such material is not included in the work's Creative Commons license and the respective action is not permitted by statutory regulation, users will need to obtain permission from the license holder to duplicate, adapt or reproduce the material.

\section{Bibliography}

Abrahamson, M. (1996). Urban enclaves: Identity and place in America. New York: St. Martin Press.

Amin, A. (2002). Ethnicity and the multicultural city: Living with diversity. Environment and Planning A, 24, 959-980.

Amin, A. (2010). The remainders of race. Theory, Culture and Society, 27(1), 1-23.

Amin, A. (2012). Land of strangers. Cambridge/Malden: Polity Press.

Anderson, B. (1991). Imagined communities: Reflections on the origin and spread of nationalism. London: Verso.

Arango, J. (2013). Exceptional in Europe? Spain's experience with immigration and integration. Washington, DC: Migration Policy Institute. http://www.migrationpolicy.org/research/ exceptional-europe-spains-experience-immigration-and-integration

Body-Gendrot, S. (2002). Living apart or together with our differences? French cities at a crossroads. Ethnicities, 2(3), 367-385.

Bourdieu, P. (1985). The social space and the genesis of groups. Theory and Society, 14(6), 723-744.

Brubaker, R. (2002). Ethnicity without groups. Archives européenne de sociologie, 43(2), 163-189.

Brubaker, R. (2006). Ethnicity without groups. Cambridge, MA: Harvard University Press.

Carter, D. M. (1997). States of grace: Senegalese in Italy and the New European immigration. Minneapolis: University of Minnesota Press.

Dench, G., Gavron, K., \& Young, M. (2006). The new east end: Kinship, race and conflict. London: Profile Books.

Esser, H. (2002). Soziologie: spezielle grundlagen, Band 6; Sinn und Kultur. Frankfurt: Campus.

Fenton, S., \& Mann, R. (2006). The state of Britain: the ethnic majority and discourses of resentment. Mobility, Ethnicity and Society Conference, University of Bristol, 16-17 Mar 2006.

Greif, G., \& Cruz, M. (1997). Reconstructing urban boundaries: The dialectis of self and place. Cybergeo: European Journal of Geography, Dossiers, Colloques "Les problémes culturels dels grandes villes", 8-12 décembre 1997, article 103, put on line 6 July 1999

Gusfield, J. R. (1975). The community: A critical response. New York: Harper Colophon.

Horowitz, D. L. (1991). A democratic South Africa? Constitutional engineering in a divided society. Berkley: University of California Press.

Jordan, G. (1990). Sub-government, policy communities and networks: Refilling the old bottles? Journal of Theoretical Politics, 2, 319-338.

Koopmans, R., Statham, P., Giugni, M., \& Passy, F. (2005). Contested citizenship. Immigration and cultural diversity in Europe. Minneapolis: University of Minnesota Press.

Lamont, M. (2000). The dignity of working man. Morality and the boundaries of race, class, and immigration. Harvard: Harvard University Press. 
Lamont, M. (2009). Responses to racism health, and social inclusion as a dimension of successful societies. In P. A. Hall \& M. Lamont (Eds.), Successful societies: How institutions and culture affect health (pp. 151-168). Cambridge, UK/New York: Cambridge University Press.

Lamont, M., \& Small, M. L. (2008). How culture matters: Enriching our understanding of poverty. In D. Harris \& A. Lin (Eds.), The colors of poverty: Why racial and ethnic disparities persist (pp. 76-102). New York: Russell Sage.

Li, Y., Savage, M., \& Pickles, A. (2003). Social capital and social exclusion in England and Wales (1972-1999). British Journal of Sociology, 54(4), 497-526.

Lynch, K. (1960). The image of the city. Cambridge, MA: Technology Press.

Marsh, D., \& Rhodes, R. A. W. (Eds.). (1992). Policy networks in British government. Oxford: Clarendon.

Massey, D. (2005). For space. London: Sage.

Okólski, M. (Ed.). (2012). European immigrations: Trends, structures and policy implications. Amsterdam: Amsterdam University Press.

Ray, K., Hudson, M., \& Phillips, J. (2008). Belonging and entitlement: Shifting discourses of difference in multiethnic neighbourhoods in the UK. In K. Tyler \& B. Petterson (Eds.), Majority cultures and the practices of ethnic difference: Whose house is this? (pp. 114-135). Basingstoke: Palgrave.

Rhodes, R. A. W. (1990). Policy networks: A British perspective. Journal of Theoretical Politics, 2, 293-317.

Rinken, S. (2011). La evolución de las actitudes ante la inmigración en tiempos de crisis económica: Un análisis cualitativo. In E. Aja, J. Arango, \& J. Oliver Alonso (Eds.), Inmigración y crisis económica. Impactos actuales y perspectivas de futuro. Anuario de inmigración en España (edición 2010) (pp. 24-47). Barcelona: Fundación CIDOB.

Rinken, S., \& Velasco Dujo, S. (2010). La evolución de la opinión públicaandaluza ante la inmigración: Indicios de estabilidad y cambio en época de crisis económica. Migraciones, 28 , $55-86$.

Salmon, H. (2002). Social capital and neighbourhood renewal. Renewal, 10(2), 49-55.

Sandercock, L. (2003). Cosmopolis. London: Continuum.

Simon, P. (2000). The mosaic pattern: Cohabitation between ethnic groups in Belleville (Paris). In S. Body-Gendrot \& M. Martiniello (Eds.), Minorities in European cities. The dynamics of social integration and social exclusion at the neighbourhood level (pp. 100-115). London: Macmillan Press.

Simon, P. (2005). Gentrification of old neighbourhoods and social integration in Europe. In Y. Kazepov (Ed.), Cities of Europe. Changing contexts, local arrangements, and the challenge to urban cohesion (pp. 210-232). Oxford: Blackwell Publishing.

Soja, E., \& Hooper, B. (1993). The spaces that difference makes. In M. Keith \& S. Pile (Eds.), Place and the politics of identity. London: Routledge Press.

Subiròs, P. (2011). Don't ask me where I'm from: Thoughts of immigrants to Catalonia on social integration and cultural capital. International Journal of Urban and Regional Research, 35(2), 437-444.

Taboada Leonetti, I. (1989). Coabitation pluri-ethnique dans la ville: Strategies d'insertion locale et phénoménes identitaires. Revues Européenne des Migrations Internationales, 5(2), 51-87.

Tonnelat, S. (2010). The sociology of urban public spaces. In W. Hongyang, S. Michel, \& Z. Guofang (Eds.), Territorial evolution and planning solution: Experiences from China and France. Paris: Atlantis Press.

Tryandafillidou, A., \& Gropas, R. (2014). European immigration, A sourcebook (2nd ed.). Farnham: Ashgate.

Vertovec, C. (2006). The emergence of super-diversity in Britain. Oxford: Centre on Migration, Policy and Society, University of Oxford.

Watt, P. (2006). Respectability, roughness and 'race': Neighbourhood place images and the making of working-class social distinctions in London. International Journal of Urban and Regional Research, 30(4), 776-797. 
Wessendorf, S. (2010). Commonplace diversity: Social interactions in a super-diverse context, MMG working paper, no 10-11, http://www.mmg.mpg.de/fileadmin/user_upload/documents/ wp/WP_10-11_Wessendorf_Commonplace-Diversity.pdf

Wimmer, A. (2004). Does ethnicity matter? Everyday group formation in three Swiss immigrant neighbourhoods. Ethnic and Racial Studies, 27(1), 1-36.

Wimmer, A. (2008). The making and unmaking of ethnic boundaries: A multilevel process theory. American Journal of Sociology, 113(4), 970-1022.

Wimmer, A. (2013). Ethnic boundary making. Institutions, power, networks. Oxford: Oxford University Press.

Wood, P., \& Landry, C. (2007). The intercultural city: Planning for diversity advantage. London/ Sterling: Earthscan. 